International Technology Management Review

Volume 2 Number 1 (October) 2009

<http://www.academicglobalpublications.com/itmr/>

\title{
Automated Digital Archive for Land Registration and Records
}

\section{Shahriar Khan}

School of Engineering and Computer Science

Independent University, Bangladesh,

14/2 A, Baridhara North Road, Dhaka - 1212

email:khandhaka@gmail.com

Phone: (880) 172-602-4831

\section{Mabruka Toaha}

Department of Computer Science and Engineering

North South University

Kemal Ataturk Ave, Banani, Dhaka, Bangladesh

Email: mabruka.toaha@gmail.com

$\mathrm{Ph}:(880)-2-988-5611$

\section{Abdul Awal}

Department of Computer Science and Engineering

North South University

Kemal Ataturk Ave, Banani, Dhaka, Bangladesh

Email: abdulawal@northsouth.edu

$\mathrm{Ph}$ : (880)-2-988-5611 


\begin{abstract}
Title: Automated Digital Archive for Land Registration and Records

Keywords: Land, Records, Bangladesh, Automated, Database

Category of paper: Research Paper

Purpose of the research/paper: The existing land management system of Bangladesh, which is largely a legacy of the British rule of India, has resisted most attempts at change for close to a century. With millions of land-related lawsuits pending, and tens of millions of people named in landrelated lawsuits, land management has been a major impediment to the economy of the country. The research attempts to computerize the existing system, within the rules of existing law, so as to reduce the widespread hardship caused to much of the population.
\end{abstract}

Methodology: Investigation of theories and practice of the existing land management system, and determination of a computerized system which best addresses the problem.

Findings: Given the background, a proposal has been made, accompanied by some minor feasibility analysis.

Value of the paper: This paper will be useful to academics, and government policymakers for land records and management. It intends to reduce the widespread hardship caused by land-related litigation in Bangladesh

Number of pages: 16

Number of tables/figures: 1 table, and 3 figures.

Section headings: Abstract, Introduction, Historical Background, Present System, Past Attempts at Computerization, Proposed System, Security Module, Graphical Module, Architecture of Proposed System, Difficulties of Change, Comparison between Present and Proposed System, Conclusion, References

(C) 2009 Academic Global Publications P/L. This work is copyright. You may download and print only one paper copy from this electronic file for your personal use only, from which you may not make any further paper copies.

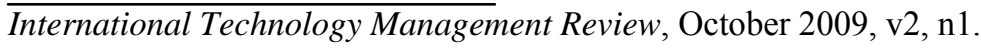




\author{
International Technology Management Review \\ Volume 2 Number 1 (October) 2009 \\ <http://www.academicglobalpublications.com/itmr/>
}

\title{
Automated Digital Archive for Land Registration and Records
}

\author{
Shahriar Khan, Mabruka Toaha and M Abdul Awal
}

\begin{abstract}
In Bangladesh, land management and registration are major barriers to economic growth. Where the present system is encumbered with vast paper records, technology and IT can greatly ease the inherent delays and difficulties of the system. This paper explores the problems related to the current system, and offers an IT-based alternative, that would be simple in implementation, yet effective and efficient. Where past attempts at computerization have been mostly unsuccessful, the proposed system should minimize hassle, expenditure, delays, and staff dishonesty. The proposed system intends to computerize all the steps, from cadastral surveying to creating new records. The publicly available satellite imagery of Google Earth software would greatly assist cadastral surveys. Diverse issues ranging from security of data to accessibility and data entry, are addressed in the paper.
\end{abstract}

\section{Introduction}

The existing land management system of Bangladesh, which is largely a legacy of the British rule of India, has resisted most attempts at change for close to a century. With millions of land-related lawsuits pending, and tens of millions of people named in land-related lawsuits, land management has been a major impediment to the economy of the country. This research attempts to computerize the existing system, within the rules of existing law, so as to reduce the widespread hardship caused to a large segment of the population.

\section{A. Background}

Land dominates the life of much of the population in Bangladesh. In this largely agrarian economy under heavy population pressure, it is essential to have a proper recording of land rights, along with a sound land management system. The existing land management system is ineffective and cumbersome, making land trading a time consuming and risky process. The weaknesses of the system 
allow its misuse in various ways, such as the illegal takeover of the land of the weak. The number of land related lawsuits stands at about 3.2 million, with the total number of accused listed at 150 million (population of the country is about 150 million). This antiquated land management system is responsible greatly for the poor law and order situation of the country.

Land transactions and records involve lengthy steps such as surveys, demarcations, record writing, attestations, hearings, etc. At present, there is no verification whether the seller of a land is the true owner of the land. Past attempts at computerization have been mostly ineffective (Bangladesh News, 2007). The proposed computerization, would be relatively simple in implementation, and hence would be more likely to succeed. The proposed method deals with all aspects from data entry, to accessibility and security.

\section{Historical Background}

The problems of the present system can be largely traced to the land management system established by the British rule of the country. For facilitating the collection of taxes, the Permanent Settlement Act of 1793 created a class of Landlords (Zaminders). Until 1916-1917 there were no real records of the proper ownership of land. In 1947, during the liberation of the Indian subcontinent, the era of landlords (Zaminders) was brought to an end, where they were now allowed to own no more than 360 Bighas of land. Commoners were allowed to own no more than 100 Bighas. Only very recently, did individuals begin to have documented ownership of land. The unclaimed areas were known as "Khas" land. Improvements in the system have been largely unable to prevent the illegal occupation of Khas lands through forged documents.

\section{Present System}

The directorate of Land Records and Surveys (DLRS) is entrusted with the responsibility of conducting cadastral surveys and maintenance of Record Of Rights (ROR) for all parcels of land. The structure of the directorate has changed considerably to meet the requirements of the changing times.

The record of rights is prepared in two steps (Figure1). The first is to draw a revised area (Mouza) map showing changes in location, area and characteristics of land. The second step is to prepare the cadastre (Khatian), including the ownership, area and character of the land. These steps complete the record of rights (ROR).

The phases followed in the survey and preparation of the ROR are (a) traverse survey, (b) plot to plot survey, (c) demarcation of boundary (Kistwar), (d) preliminary record writing (Khanapuri), (e) local explanation (Bujharat), (f) attestation, (g) draft publication, (h) hearing of objections, (i) appeal, (j) final checking (Junch), and finally (k) printing and publication of the cadastre (Khatian).

\section{A. Land Sale Registration}

When the buyer and the seller of a parcel of land come to an agreement on the transfer, a deed is prepared on the stamp of required value with the help of a deed writer. It is then presented before the sub-registrar for his registration and official seal. Both buyer and seller appear before the sub-

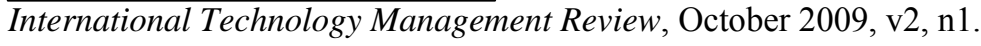


registrar who takes cognizance of the land transfer and signs and seals the documents. The registered deed is copied in the relevant volume, and it takes about 9-12 months to get the registered deed. Ten percent of the cost is levied as tax.

One fundamental aspect of land registration is that it is merely the record of an isolated transaction. It shows that a particular transaction took place without establishing whether the parties are legally entitled to do so. Registration takes place without any critical examination of relevant records. This registration of deeds in Bangladesh has been in force since the Registration Act of 1908.

The land records kept in the Tehsil office are not checked to verify whether the seller is the real owner of the land, or if anyone else has any interest in the land. False registration occurs both in urban and rural areas, but the incidence of false registration is much higher in urban areas. A plot of land may be sold to different people leading to decades-long litigation.

The deed prepared by the writers contains many unnecessary words and sentences, thus creating further room for improvement.

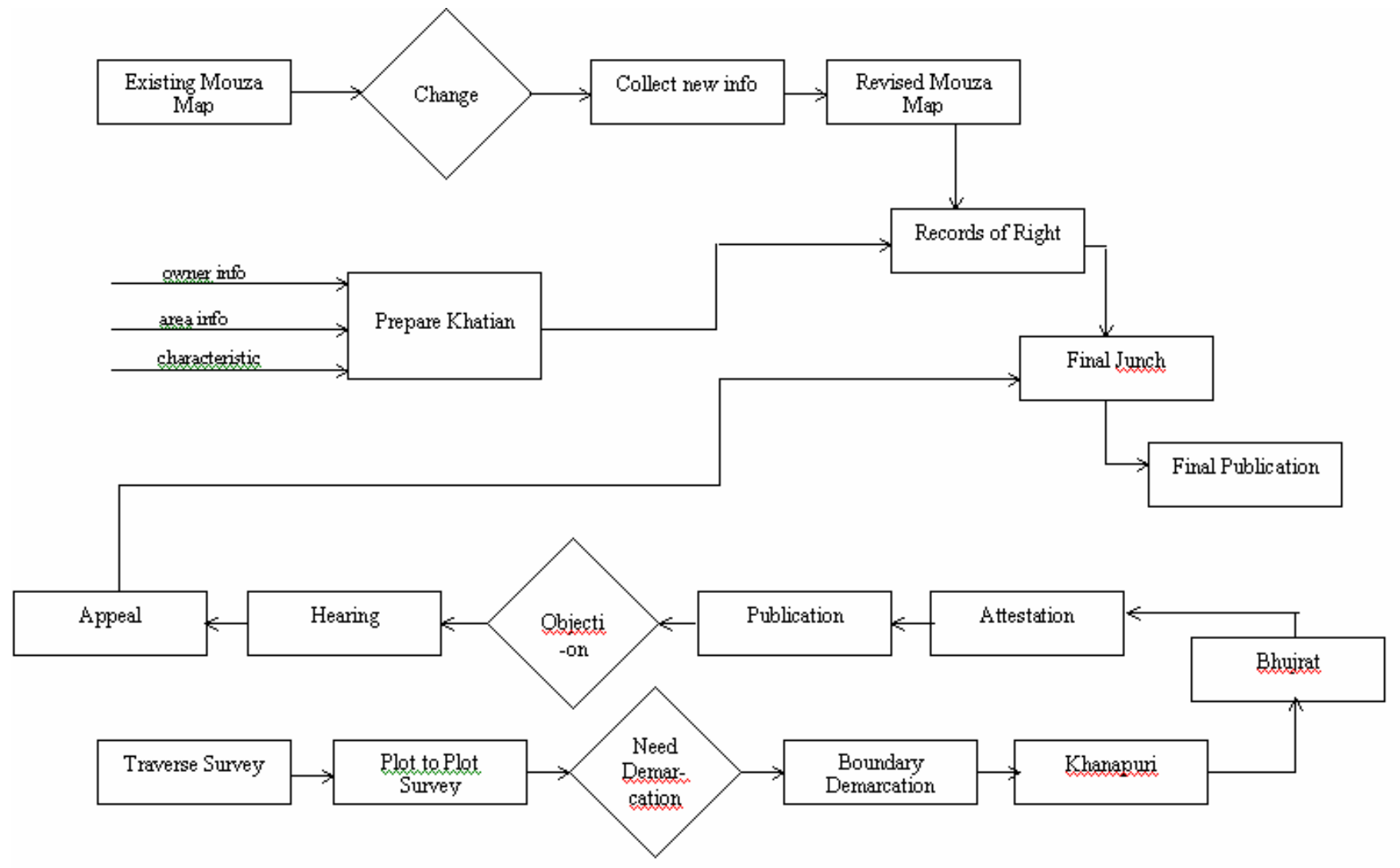

Figure 1 Present Land Sale System

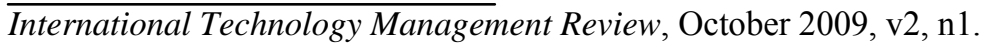




\section{Land Mutation Process}

Mutation refers mainly to the transfer of title. There are two ways a mutation process can start, namely:

- $\quad$ Mutation according to land transfer (LT)

- Mutation in response to application

When the ownership of land is changed due to sale or otherwise, and this change of ownership is registered, the sub-registrar, under the Transfer of Property Act and Registration Act, sends a land transfer notice to the Thana Land Office. On receipt of the LT notice the AC (Land) starts a case for updating the record of rights or ROR.

The updating of record of rights is also done during a settlement operation. When there is no settlement operation, this is done by the AC (Land)/ Thana Revenue Officer under section 143 of the East Bengal State Acquisition and Tendency Act, 1950 on receipt of an application from the tenants.

In case of mutation through inheritance, after getting information of death of tenant, the land officer (Tehsildar, today known as Union Bhumi Shohokari Kormokorta) may send a notice to the incumbent. The party/incumbent may also apply for mutation indicating their share according to the law of inheritance. Generally the successor-in-interest applies for mutation of holdings.

In Bangladesh, mutation due to the both inheritance and sale are common. In 1994, the average number of mutation cases filed in Part I (mutation due to inheritance) was 23,893 / month. Part II type of mutation numbered at 46,828. In the same year, the monthly average number of mutation cases disposed of in Part II and Part I were 21,496 and 16,778 respectively. The overall average monthly disposal in each month was 8,554 , and the cumulative figures are increasing every year.

\section{Past Attempts at Computerization}

A Computerized Land Management System (CLMS) was introduced in Dec. 2004 in the Demra area of Dhaka, with an initial allocation of Tk. 97 lakh (US\$ 140,000), with the intent of reducing public suffering, and stopping land grabbers (News from Bangladesh 2004, The Daily Star 2006). Under the CLMS, information on every land, its sales, transfers, current and former ownerships, categories of use, were to be compiled and stored in a readily accessible database in line with the land settlement record of 1969 and 1983. The system was expected to greatly reduce the number of land disputes, as fake documents would be hard to come by, and would have little legal use. The Centre for Environmental and Geographic Information Services (CEGIS) was awarded the job to develop a software system to keep land records, which they did successfully. The government then allocated Tk. 2.27 crore (US\$ 325,000) for setting up similar systems in four more zones - Dhaka Kotwali, Tejgaon, Mirpur, and Dhanmondi.

The second phase of the project was awarded to Development Planners and Consultants, DPC.

By April 2007, the project was gathering dust for various reasons (Bangladesh News 2007). The funds allocated for the second phase of the project was already used up, while the work had not even started in many areas.

International Technology Management Review, October 2009, v2, n1. 


\section{Proposed System}

\section{A. Strategic Approach to the Proposed System}

Based on the steps and processes in the existing paper-based system, the following objectives are stated:

* Developing a digital archive and retrieval system,

* Automating manual procedures, so as to reduce errors, increase speed and accuracy, and reduce employee time required.

* Smoothing the land purchase and sale registration process,

* Reducing law suits related directly or indirectly to land,

* Introduce transparency in the government thereby reducing corruption.

The proposed computerized system is to be transparent, and accessible to both government departments (facilitating e-governance) and to the public.

The proposal will not only result in reduction of costs for land record access but also facilitate easier information distribution and dissemination. The software to be implemented will provide all the graphical display, query and edit capabilities of any conventional GIS software. It is to have a robust module for data entry and data maintenance. The noteworthy aspects of the software will be the security features, which cater to the very high security needs of land records transactions.

\section{B. Detailed Mapping}

Information on the area and location of land can be collected through four different approaches:

(a) Ground Survey,

(b) Aerial/Satellite Photography,

(c) GPS based data collection system and

(d) Existing information of lands in the land offices.

(e) the new Google Earth software

Vertical air photographic techniques (from (a) above) is well suited for cadastral mapping in Bangladesh. Its primary advantage is its flatness and air visibility of plot boundaries. A scale of 1:12,000 will be sufficient in most areas. The main steps in aerial survey are to consist of:

i) taking of photographs,

ii) rectification $(1: 12,000$ scale $)$,

iii) correction in site,

iv) providing a survey number,

v) area calculation,

vi) preparation of draft Khasra,

vii) preparation of map with internal details,

viii) public review of draft Khasra and map

ix) and the final publication.

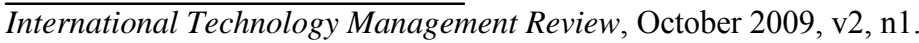


Aerial photography has the advantage that it should reduce the time for conventional cadastral settlement operations of about ten years by at least three years. It should yield much more accurate results. The publicly available software of Google Earth allows detailed viewing of satellite pictures (Figure 2). It is recommended, all the data available for Bangladesh be downloaded. This data is to greatly prove its worth for the land management of Bangladesh.

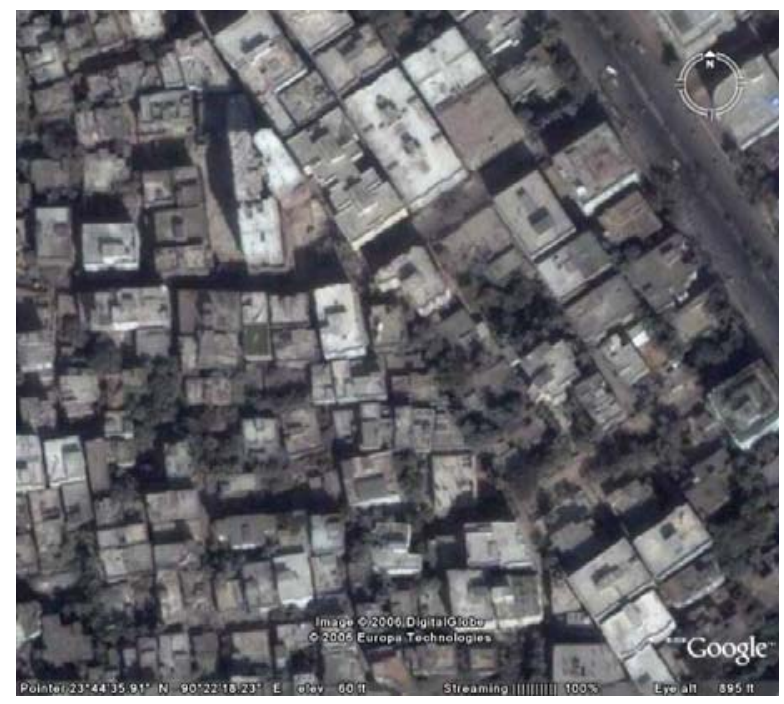

\section{Figure 2 Google Earth image of well planned Dhanmondi (right) next to less-planned Hajaribagh (left)}

\section{Creating Effective Database}

In the existing procedure, the land records stored in the Tehsil office are not checked to determine whether the seller is the real owner of the land. Retrieval of any information from the volumes of registers is very difficult. Computerization of registration records would greatly facilitate the easy retrieval of registration records. The proposed system would computerize and automate all the manual activities of land records and tax. It is to have a simple format with the necessary information for the conveyance of the property. The database will contain information such as names and occupations of both buyer and seller, with their present and permanent addresses, the particulars of the land (lot number, JL number, name of Mouza), the mode by which the seller became the owner of the plot (i.e. purchase, inheritance, etc.), the classification of land, area of land, boundary demarcation, the value at which the land is being transferred, tax etc. In case of property inheritance, the buyer field will be replaced by the present owner, and the seller field will be replaced by the previous owner. The database should:

- Ensure that the stored data can be used for a variety of applications like: record keeping, land registration, mutation, property tax and capital gaind collection and dispute resolution.

a Maintain data that is both accurate and consistent and avoid data redundancy.

- Ensure purposeful information retrieval system so that all the data required for current and future applications are be readily available.

a $\quad$ Ensuring efficient upgrading system etc.

International Technology Management Review, October 2009, v2, n1. 


\section{Database Organization (Logical and Physical Views)}

As the database is to be shared by many users, users at different levels will have different user schema. After examining the requirements, an overall logical model of the database will be developed. Finally, the logical model of the database will be transformed into a corresponding physical database design. The physical design will involve fundamental information on how data will be stored and related as well as how they will be accessed.

\section{E. Features of the Proposed System}

The Land Information Management Systems software will be an integrated system wherein the user will be provided with the facility to navigate and perform all operations from Data Entry to Data Validation to Records Display through one single Interface. The main modules available in the LIMS will be as follows:

Data Entry Module: The Data Entry Module will have interfaces to enter data of the registers that are maintained for revenue purposes. One can view and take prints for each register. The option to view and list the contents of the registers will be provided.

Security Module: (described below)

Graphical Module: (described below)

\section{Security Module:}

Considering the confidential and sensitive nature of the land records, the issue of security is to be given the highest priority while designing the software. Salient features of the security setup will be:

(a) Restricted user access to records wherein only authorized land functionaries have permission to edit records in the database.

(b) Digital signature for authentication; All relevant employees will have the option to encrypt their digital signatures in the document that they will handle.

(c) A separate module for tracking each and every transaction that takes place in the database along with the name of the user responsible for such action.

(d) Backup facility to help in regeneration of past records in case of accidental or deliberate deletion.

\section{A. Logical Level:}

The system will permit those with correct passwords or authorization codes to enter the system or a particular part of the database. There will be at least three different level of security access, which will be maintained at three separate levels:

Level 1: Employed personnel at the supreme level will be allowed to view all the stored land records. They will be allowed to add, delete, and edit land records related to buying, selling and mutation of land. They will also be allowed to view the taxation records on a certain piece of land.

Level 2: Employees at the second level will be allowed to view, add and edit existing data, i.e. they will be able to store land sell and mutation records. However, to delete any land record

International Technology Management Review, October 2009, v2, n1. 
from the database, they will require special permissions or they will have to hand over the word to the level 1 user.

Level 3: The database will have a limited portion of the each entry as "read only to all". Any one interested to view the buying and selling records on any piece of land will be able to do so by paying the government fees.

\section{Graphical Module}

This module will be developed using $\mathrm{VC}++$ and Active $\mathrm{X}$ components, and will have a linkage with the GIS software. This is primarily the map display module of the system. It will provide all the tools that are available in any of the Graphic Viewer Software of international repute. The noteworthy features of the graphical module will be:

1) Map Display

2) Display the maps within a predefined window area.

3) Zoom In, Zoom Out, Pan View, Fit View, Refresh View, and Window Zoom facilities.

4) View of legends like schools, mosques, graveyards etc.

5) Edge-matched maps within the villages so that one village will correspond to one map in the digital environment. However, in the real world, a village map may well be distributed over multiple sheets.

6) The spatial database (maps) generated on a true scale thus keeping the dimensions accurate.

\section{A. Query Capabilities}

The system will provide facility to query on the owner name, cadastre number (Khatian) in addition to random selection of parcels from the map and querying on them. Since the spatial and the textual data will be integrated, all queries will have spatial components, which will give the user the flexibility to pinpoint locations on the map. In addition, a number of reports will be designed keeping the daily requirements of the district administration in view. The reports to be available in the proposed system will include:

1) List of Government owned lands

2) List of revenue assigned land's

3) Status of mutation transactions

4) Mutation types.

\section{Architecture of the Proposed System}

The proposed network system is to have a decentralized structure (Figure 3). A computer at the district level will act as the local server, whereas all other machines installed in the Thana headquarters and other focal points will be designated as clients. Connectivity between the clients and the local server will be established by available means, such as Wi-Max. The local servers at the district levels can be connected to the main server via the optical fiber backbone of Bangladesh Railway.

The software will be designed following the client/server architecture in order to improve the usability, flexibility, interoperability and scalability of the solution as compared to a

International Technology Management Review, October 2009, v2, n1. 
centralized system. Here, a client will be defined as a requester of services and a server as the provider of services.

\section{A. Technical Feasibility:}

Based on the district and Thana structure, the proposed system requires about 534 computers and 138 printers, distributed to all the corners of the country.

Number of computers:

Client computers at the Thana levels : $460 \times 1=460$

Local servers at the District levels : $\quad 64 \times 01=64$

Main server and backups at the Capital : $\quad 10+10=20$

Total computers :

$$
=544
$$

Number of Printers:

Printers with local servers : $\quad 64 \times 2=128$

Printers with Main servers : $\quad=10$

Additional printers : $\quad=20$

Total printers: $\quad=158$

Capital expenditure (Tk.):

Central database center $\quad=900,000,000$

Total number of land offices nationwide $\quad=496$

Each land office automation establishment cost

$$
=6,000,000
$$

Total cost for land office automation

$$
\begin{aligned}
& =6,000,000 \times 496 \\
& =2,978,000,000
\end{aligned}
$$

Grand total $\quad=(2,978,000,000+900,000,000)$

$=3,876,000,000$

In 2001-2002, the country-wide land tax was estimated at Tk 7,919,172,000. The government has collected only 42 crore taka in 2003 . The new system can greatly facilitate the collection of taxes, hence clearly paying for itself.

\section{B. Monthly Operational Cost for New System}

Central Database Center $\quad=11,000,000 \mathrm{Tk} / \mathrm{month}$

Total number of Land Offices Nationwide $=496$

Each Land Office $\quad=110,000.00 \mathrm{Tk} / \mathrm{month}$

Total for Land Office $\quad=110,000.00 \times 496$

$=54,560,000 \mathrm{Tk} /$ Month

Grand Total $=(54,560,000+11,000,000)$

$=65,560,000$ Taka/ Month 


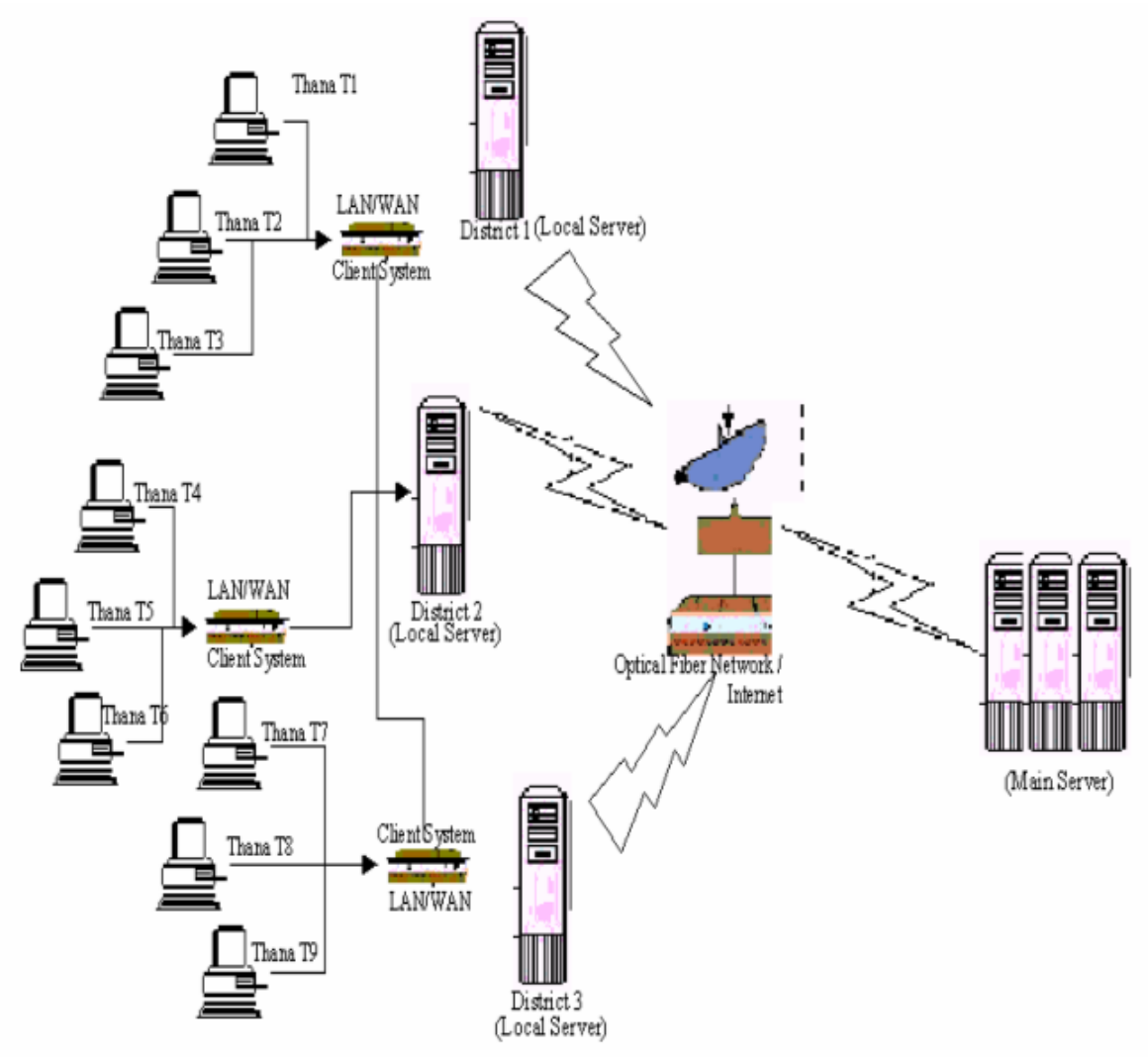

Figure 3 Architecture of the Proposed System

\section{Difficulties of Change:}

There will be several obstacles to moving forward from the present land management system to the proposed system. Some of the difficulties the new system has to overcome are:

* The Directorate of Land Records and Survey has earned notoriety for corruption and inefficiency.

* The low level stuffs are temporary and they try to make as much as they can through corrupt practices.

* Powerful land owners try to induce officers to do undue favors.

* Corruption exits at the stage of attestation and objection hearing.

If the new system is implemented, not only will the corrupt system come down, the previous records of the employees will be exposed to the public. Strong opposition from existing employees is to be expected.

\section{Comparison Between Present and Proposed System}

The proposed Land Information Management System will help to improve efficiency and processing (Table 1). It can be an effective database, providing accurate information to both International Technology Management Review, October 2009, v2, n1. 
officials and the public. It will give a secure access of data and also check unauthorized manipulation. The system will speed up the present system significantly, introducing transparency in the government, and reducing corruption. Having a Relation Database LIMS can be integrated to other e-Governance Applications.

Table 1 Comparision of Present and Proposed Systems

\begin{tabular}{|c|c|c|c|}
\hline Function & Process & Present System & Proposed System \\
\hline \multirow{6}{*}{ 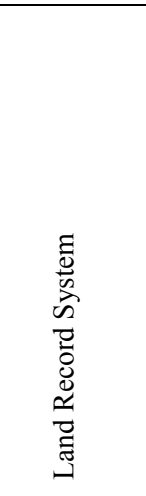 } & Updating & $\begin{array}{l}\text { Highly time consuming. } \\
\text { About } 46 \text { years will be } \\
\text { needed for total updating }\end{array}$ & $\begin{array}{l}\text { Updating will be done } \\
\text { immediately after the change. So } \\
\text { no extra time will be needed. }\end{array}$ \\
\hline & Intricacy & High intricacy & No intricacy \\
\hline & Objection/Appeal & $\begin{array}{l}\text { Takes several months to } \\
\text { years for completion }\end{array}$ & A few days will be needed \\
\hline & Manpower & $\begin{array}{l}\text { DLRS has a total of } 9098 \\
\text { stuffs for survey on payroll }\end{array}$ & $\begin{array}{l}\text { Not more than one thousand } \\
\text { people will be needed for the job }\end{array}$ \\
\hline & Printing time & $\begin{array}{l}\text { At least } 28 \text { years are required } \\
\text { for printing all Khatians with } \\
\text { current setup }\end{array}$ & $\begin{array}{l}\text { It may take a few days for a } \\
\text { whole Thana \& the job can be } \\
\text { done at several Thanas } \\
\text { simultaneously }\end{array}$ \\
\hline & Printing Cost & About 400/- per Khatian & About 2-3/- per Khatian \\
\hline \multirow{6}{*}{$\neg \approx \approx \tau$} & Backlog & High backlog & No backlog \\
\hline & Amount of Printing & 10 copies per Khatian & $\begin{array}{l}\text { As much as needed, whenever } \\
\text { needed. }\end{array}$ \\
\hline & Integrity & $\begin{array}{l}\text { No linkage between DLRS } \\
\text { \& Collectorate setup }\end{array}$ & $\begin{array}{l}\text { A linkage will be developed } \\
\text { through computerized networked }\end{array}$ \\
\hline & $\begin{array}{l}\text { Information } \\
\text { Dissemination }\end{array}$ & $\begin{array}{l}\text { No information } \\
\text { dissemination. The record is } \\
\text { kept in the office where the } \\
\text { transaction occurred }\end{array}$ & $\begin{array}{l}\text { Information will be disseminated } \\
\text { through computer network }\end{array}$ \\
\hline & $\begin{array}{l}\text { Immoral Behavior of } \\
\text { Land Buyers }\end{array}$ & $\begin{array}{l}\text { Tendency of understating } \\
\text { actual land value for paying } \\
\text { less stump duty }\end{array}$ & $\begin{array}{l}\text { Due to stored up-to-date price } \\
\text { no opportunity of understating. }\end{array}$ \\
\hline & Deed Registration & Takes 9-12 months & 1-7 days will be required \\
\hline
\end{tabular}

\section{Conclusion:}

Land registration in Bangladesh, a complicated process with numerous overhead costs, is a barrier to the economic growth of the country. Maintenance and changes in the Record of Rights for the land involves numerous complicated processes that are legacies from the British rule of Bengal. A major loophole in the system, dating back from the Registration Act of 1908, is that there is little or no verification whether the seller of a land is the true owner of the land.

The backdated land record system has resisted change for many decades, largely due to resistance from beneficiaries of the existing system. Past attempts at modernization, such as the well-intentioned CLMS of Dec. 2004, have been driven to the ground, with various reasons being cited for their failure.

The proposed system has been structured, keeping in mind both fundamental concepts of computerized data records, and the practical problems of implementation in the country. The proposal is to develop a digital archive and retrieval system. Manual procedures should be automated so as to reduce errors and improve speed. The system is to be transparent, so as to reduce corruption, and be accessible to the government, the judiciary, and the public. The detailed mapping for the system should take the help of the new satellite imagery database of 
Google Earth software. This paper demonstrates how the proposed system has the potential of becoming an effective replacement to the existing system.

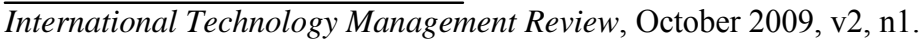




\section{References}

Acharya, B. P. 1987, "Policy of Land Acquisition and Development - Analysis of an Indian Experience," Third World Planning Review, vol. 9, No. 2, Liverpool University Press, United Kingdom, 1987.

Beachboard, J. C. 2003, "Automating Land Management: An interpretive analysis of information technology management within the bureau of land management." 36th Hawaii International Conference on System Sciences, Proceedings on, 2003.

Brammer, H., 1984, Land Use Planning in the Tropics. ADAB News, vol. XI, No. 1, Dhaka, 1984.

Brownlee, J. 1998, Managing information to national standards, 1998.

Burrough, P.A. and McDonnell, A., 1998, Principles of Geographical Information Systems, Oxford University Press, New York, ISBN 0-19-823366-3, 1998.

"Computerized land management system introduced," News From Bangladesh, December 3, 2004, viewed Feb. 9, 2009, <www.bangladesh-web.com>.

"Computerized land management system in Dhaka," The Daily Star, Law and our Rights, Sept. 2, 2006, viewed Feb. 9, 2009, <www.thedailystar.net>.

Local Government Management Board (LGMB) Information society news, Vol. 1, issue 1, pp $9-11$.

"Project gathers dust, funds for phase II gobbled up," Bangladesh News, Saturday, April 14, 2007, viewed February 9, 2009, <www.bangladeshnews.com>.

Jin, P., Wan. S., Yue, L., 2007, "A semantic framework for spatiotemporal data representation," Third International IEEE conference on Signal-Image Technologies and Internet-based systems, 16-18 Dec. 2007.

Kalam, N. \& Khan, S, 2005 "Proposal for implementing GIS based land information system in Bangladesh," Prospects and Problems of Mobile and Land Phones in Bangladesh, Proceedings of, Independent University, Bangladesh, Dhaka, 8 Dec. 2005.

Marulanda, L. \& Steinberg, F. 1991: Land Management and Guided Land Development in Jakarta.

Nawaz, M., Sattar, F., 2008, "Sustainable land use using consensus mapping and conflict resolution," Aerospace and Electronic Systems Magazine, IEEE, Volume 23, Issue 7, pp. 32 38 , July 2008.

Soetojo, H., Rukmana, N. and Steinberg, F., 1990, "Problems and Issues of Land Development for Jakarta's Low-Income Families" and Triaco on the Guided Land

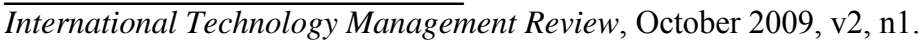


Yang, L. T., Park, H. J., Kim U. N. 1993, "On the application of land information system for land management," Geoscience and Remote Sensing Symposium, 1993. IGARSS '93. Better Understanding of Earth Environment., International, pp. 924 - 926 vol. 2, Aug. 1993.

(C) 2009 Academic Global Publications P/L. This work is copyright. You may download and print only one paper copy from this electronic file for your personal use only, from which you may not make any further paper copies.

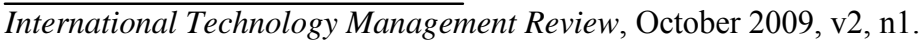

